\title{
Przepisy na kosmetyki w ,galeno-chymicznym” manuale Andreasa Happena (1660)
}

\section{Artur Koniewicz, Zbigniew Bela}

Muzeum Farmacji UJ Collegium Medicum

Adres do korespondencji: Zbigniew Bela, ul. Floriańska 25, 31-019 Kraków

$\mathrm{M}$ anuał Happena to jeden z licznych aptekarskich manuałów, jakie są przechowywane w bibliotece krakowskiego Muzeum Farmacji.

Andreas Happen (1638-1698) był właścicielem założonej w 1677 r. Hagenmarkt-Apotheke w Brunszwiku (ilustracja 1), a także wyłącznym dostawcą wszystkich aptecznych artykułów dla dworu księcia Rudolfa Augusta ${ }^{1}$.

Swój manuał sporządził Happen w 1660 r., kiedy byl jeszcze aptekarskim uczniem (ilustracja 2). Jest to gruby (672 strony), oprawiony w pergamin notatnik formatu $16 \times 9 \mathrm{~cm}$, liczący w sumie 328 przepisów, które zostały podzielone na dwie części, każda z własną paginacją. W pierwszej, zatytułowanej Chymica quadam, umieścił autor, w kolejności alfabetycznej, 229 przepisów na leki „chymiczne”, czyli uznawane wówczas za nowoczesne, w drugiej 99 przepisów na leki tradycyjne, które

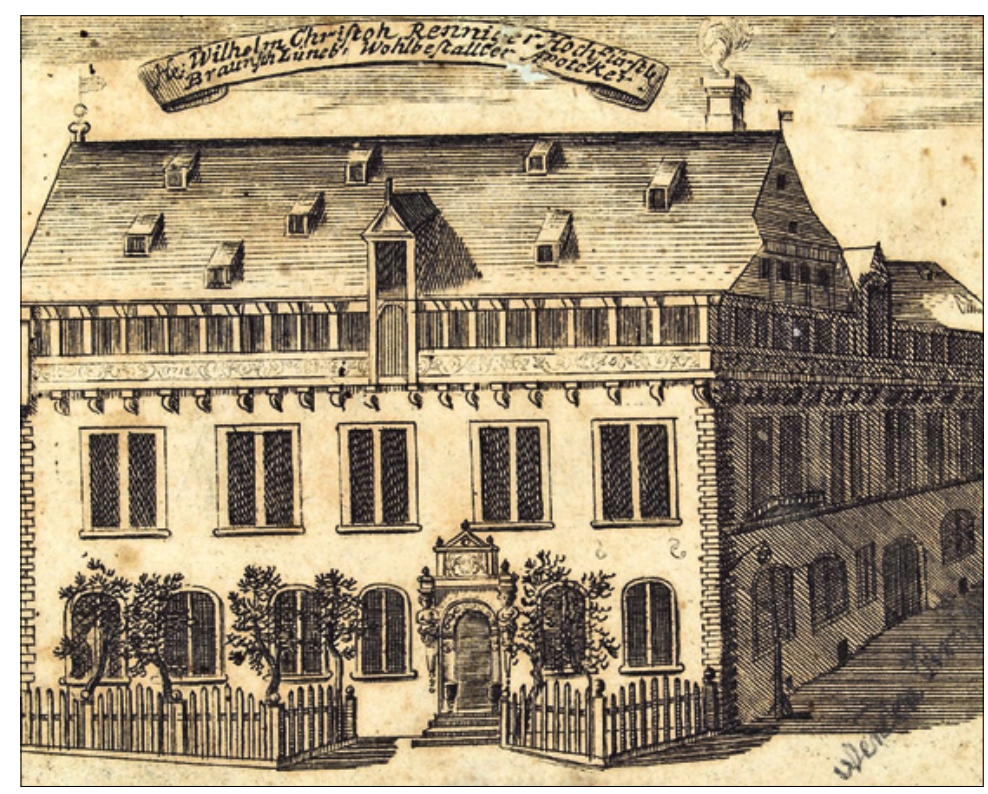

Ilustracja 1. Hagen-Markt Apotheke w Brunszwiku. Grafika Johanna Becka z $1718 \mathrm{r}$. opatrzył tytułem De galenicis. Po alfabetycznym spisie przepisów z części pierwszej (strony 5-42) na dwóch następnych zamieścil też autor tablicę stosowanych w niej symboli alchemicznych. Alfabetyczny spis przepisów „galenowych” znajduje się na stronach $343-367^{2}$.

Od innych przechowywanych w krakowskim Muzeum Farmacji aptekarskich manuałów, w liczbie 45, manuał Happena różni się przynajmniej pod trzema względami. Po pierwsze, jest zdecydowanie najstarszy - pochodzi, jak już wspomniano, z XVII wieku, podczas gdy pozostałe są z XIX i pierwszej polowy XX w. Po drugie, zamieszczone w nim przepisy dotyczą tylko leków i kosmetyków, podczas gdy w pozostałych manuałach mamy też przepisy na wiele innych rzeczy - na farby i atramenty, słodycze i spirytualia, pasty do butów i smary do kół, preparaty do zwalczania szkodników, przepisy na ognie bengalskie itp. I po trzecie: większość tych manuałów powstawała zwykle w dłuższym okresie, przez okazjonalne dopisywanie kolejnych przepisów, niezależnie od ich charakteru; natomiast manuał Happena zostal sporządzony „za jednym zamachem” - na co wskazują m.in. opisane wyżej, formalne cechy jego opracowania.

Wśród przepisów „chymicznych” w manuale Happena, który jest rękopiśmienną formą siedemnastowiecznego, drukowanego piśmiennictwa tego rodzaju (zob. przypis 2), znajdujemy przepisy na preparaty rtęci, antymonu, arsenu, potasu, miedzi, ołowiu, srebra, złota, żelaza itd., takie na przykład jak Antimonium tartarisatum (winian antymonowo-potasowy, dawna polska nazwa: „winnik wymiotny”), Regulus antymonii ${ }^{3}$ (zalecany na puchlinę wodną i świerzb), Flores Antimonii albae et rubrae (,kwiaty antymonowe biały i czerwony”, odpowiednio tlenek antymonu i tlenosiarczek antymonowy), Oleum Arsenici (arsenian potasu, zalecany wyłącznie do celów chirurgicznych), Crocus Veneris (,„szafran miedzi”, czerwony tlenek 
miedzi, zalecany jako składnik plastrów rozgrzewa jących), Lac sulphuris („mleko siarczane”, związek siarki i wajnsztynu, zalecany na choroby ,piersiowe”), Cinabrium praecipitatum diaphoreticum (,precypitat cynobrowy napotny”), Crocus metallorum (,szafran metali”, związek antymonu i potasu), Flos Lunae (,kwiat srebra”, preparat srebra i kwasu siarkowego, zalecany na „tumory złośliwe i niezłośliwe”) i Aurum fulminans (,złoto wybuchające”, zwane też ,piorunianem złota” - związek złota, wajnsztynu i chloru, zalecany jako środek napotny i nasercowy) (ilustracja 3).

W części „galenowej” zamieścił Happen przepisy na takie m.in. tradycyjne preparaty, jak: Balsamum vitae („,balsam życia”), Loch de pulmone vulpis (, loch $^{4} \mathrm{z}$ płuc wilka”) czy Unguentum stomachale („maść żołądkowa”), których opisy są znane od czasów Galena (II wiek n.e.) lub Avicenny (XI wiek) i które można znaleźć też w średniowiecznych i wczesnonowożytnych lekospisach. Jako rzecz charakterystyczną w tym kontekście należy potraktować fakt, że nie ma wśród nich przepisów na dwa sztandarowe leki dawnej farmacji,

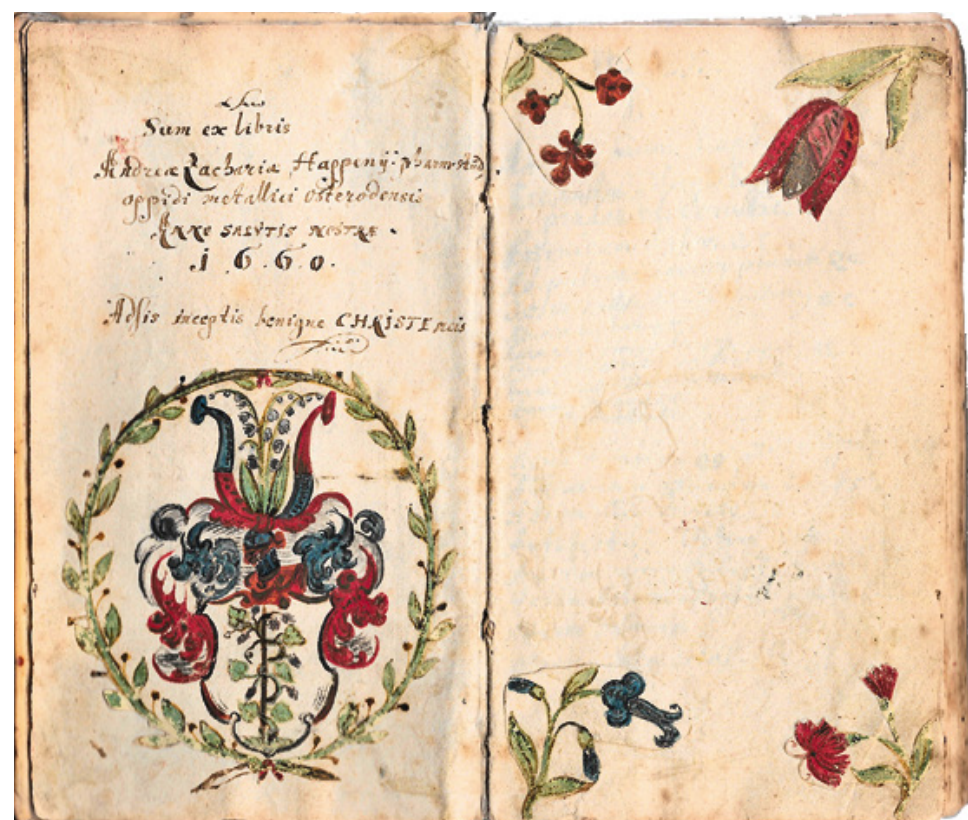

Ilustracja 2. Frontispis manuału Happena: ,Jestem z książek Andrei Zachariasza Happena, ucznia aptekarskiego w górniczym mieście Osterode. Obyś sprzyjał moim zamiarom, łaskawy Chryste. Roku Pańskiego 1660"
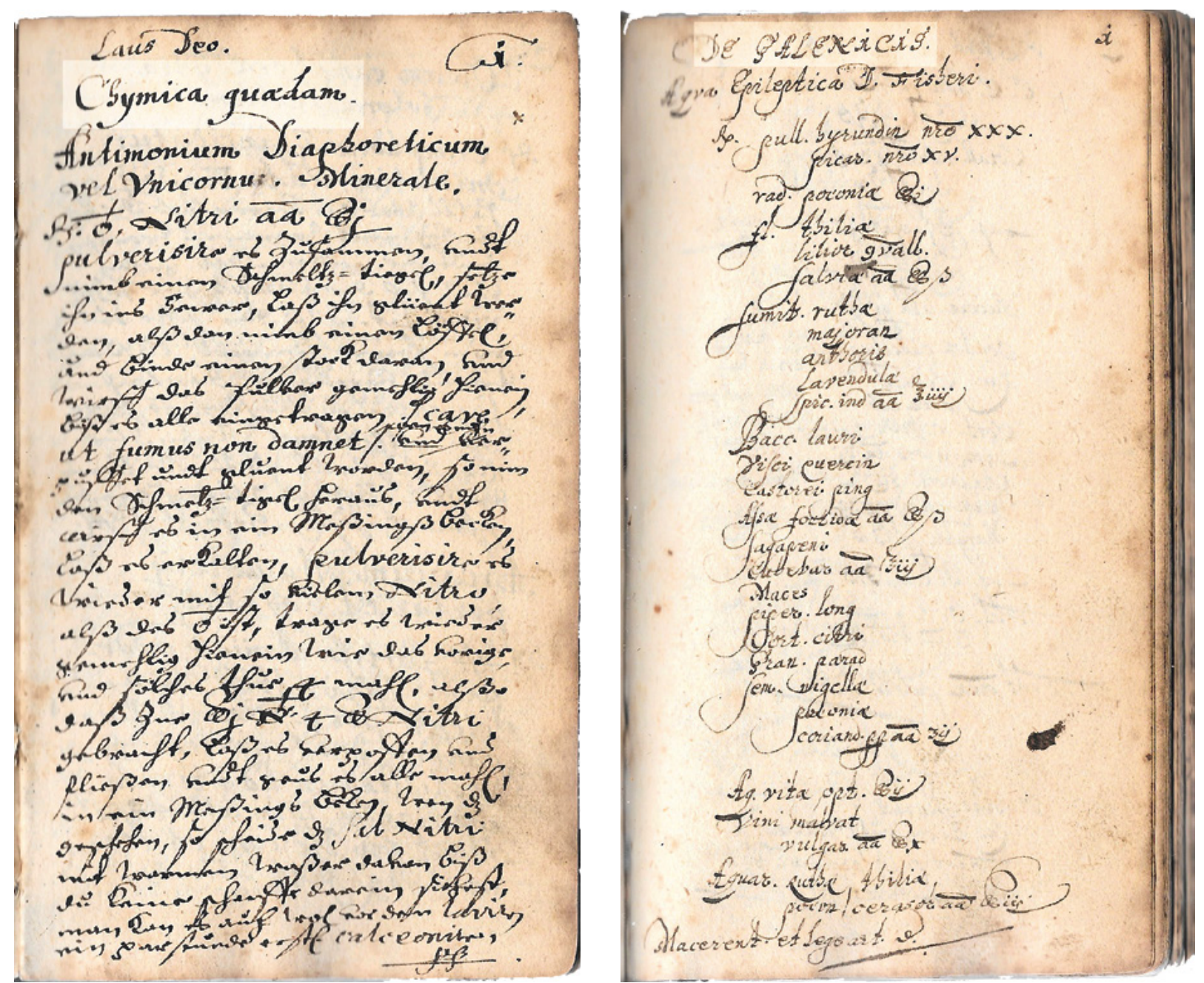

Ilustracja 3. Strony początkujące część „,chymiczną” i część „galenową” w manuale Happena 


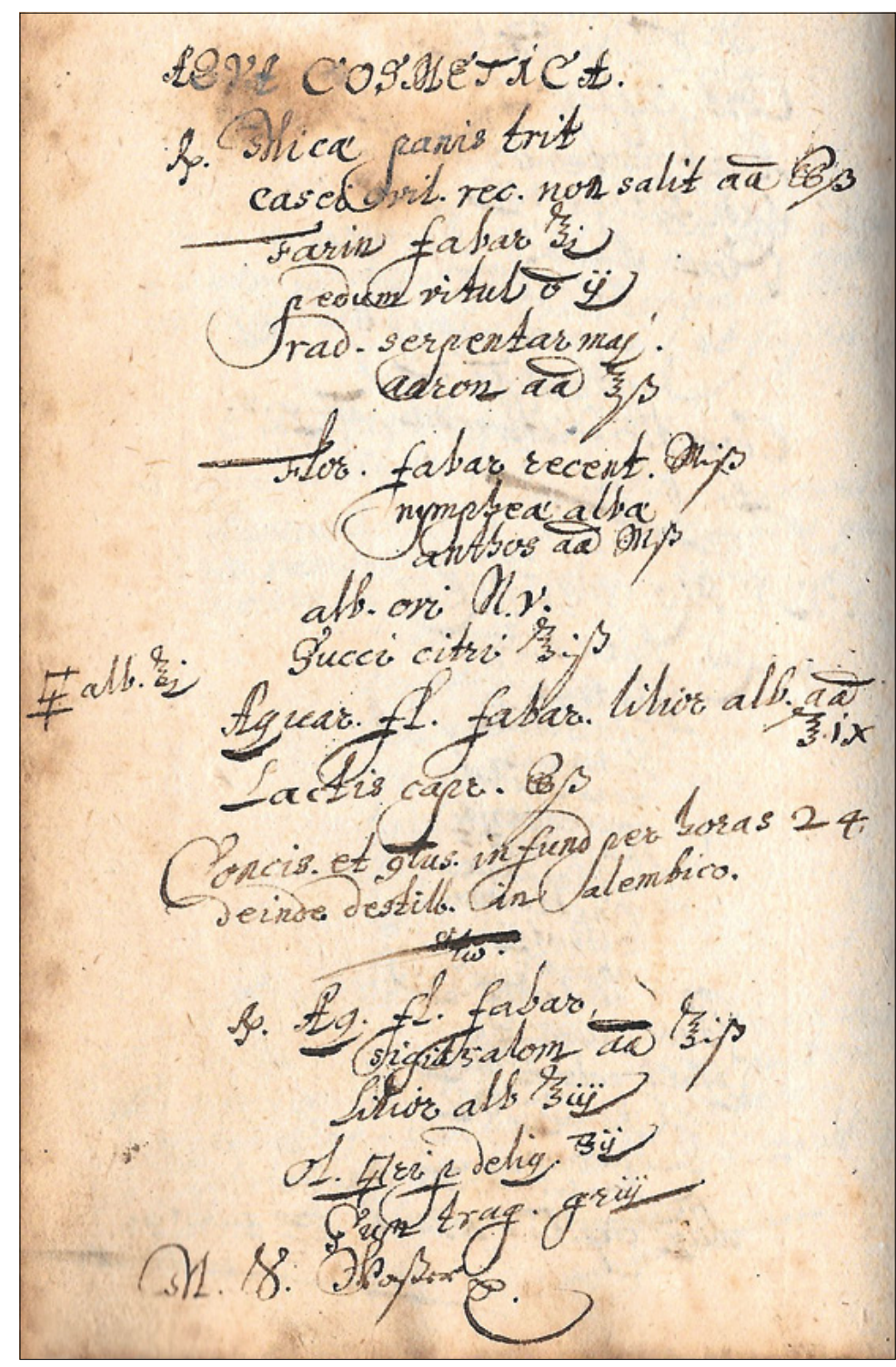

Ilustracja 4. Przepis na wodę kosmetyczną w manuale Happena

za jakie do XIX w. włącznie uchodziły teriak i mitrydat. Czyżby młody Andreas Happen już wtedy, sto lat przed Heberdenem ${ }^{5}$, chcial dać do zrozumienia, że nie wierzył w przydatność owych „wspaniałych antidotów"? A jeśli tak, to czy informacja ze wspomnianego na początku tego artykutu żatobnego wspomnieniu Ermischa, że Happen „zaledwie pół roku temu robił teriak i mitrydat”, to tylko licentia poetica czy może jednak prawda - co z kolei oznaczałoby, że Happen, mimo iż nigdy nie wierzył w skuteczność obu tych leków, to jednak je robil i sprzedawal, ponieważ caly czas przynosiły one duże zyski?

Przepisy na kosmetyki w manuale Happena znajdują się wyłącznie w części galenowej. W sumie jest ich sześć, ich tytuly to Woda kosmetyczna, Balsam lawendowy, Balsam jabtkowy, Proszek do zębów, Woda na dziąsta i pozbawiony tytułu przepis na mydto białe pachnące.
Przepis na wodę kosmetyczną jest następujący:

Pokruszonego miękiszu chleba pszennego

Sera owczego niesolonego pót funta

pót funta

Mąki fasolowej jedna uncję

Dwie nogi cielęce ${ }^{8}$

Korzenia wężownika pót uncji

Kwiatów fasoli pót garści

Grzybienia biatego $i$ kwiatu rozmarynu po pótgarści

Biatka jaja jedna uncje

Soku cytrynowego póttorej uncji

Wody (destylatu) z kwiatów fasoli

Koziego mleka pót funta iz kwiatów lilii po dziewięć uncji

Wymieszaj i odstaw na 24 godziny.

Zastosowany w tytule tego przepisu wyraz woda jest o tyle mylący, że sugeruje wodnisty charakter preparatu - a przecież niektóre z jego składników, takie jak pokruszony chleb, ser owczy czy mąka fasolowa wyraźnie wskazują, że cały preparat miał raczej gęstą konsystencję. „Woda” ta musiała też być dość tłusta, ze względu na owczy ser i nogi cielęce miała więc charakter odżywczy; a także ochronny na przykład przed pierzchnięciem skóry z powodu chłodu. I też nawilżający, jako że nogi cielęce zawierają dużo kolagenu, który ze względu na dużą masę cząsteczkową nie ma możliwości przenikania do głębszych warstw naskórka. Mógł też mieć działanie kojące, ze względu na zawartą w nim mąkę fasolową, która od najdawniejszych czasów była stosowana w postaci okładów na skórę chorobowo zmienioną (egzema, oparzenia, wrzody itp.). Wchodzące w skład tej „wody” świeże kwiaty fasoli, rozmarynu i grzybienia działały nawilżająco i nadawały preparatowi przyjemny zapach, a te ostatnie mogły też działać kojąco na podrażnienia skóry, ze względu na przeciwbakteryjne właściwości zawartych w nich kwercetyny, apigeniny i kamferolu. Białko kurzego jaja zawiera dużo aminokwasów, które odżywiają, a także sklejają warstwę rogową naskórka, tworząc swego rodzaju okluzję9. Sok cytryny, oprócz tego że ma świeży zapach, działa też silnie tonizująco i przeciwbakteryjnie, podnosi pH skóry, lekko rozjaśnia płytkie przebarwienia. Tzw. woda (de facto destylat) z kwiatów fasoli działa identycznie jak opisana wyżej mąka fasolowa, woda liliowa działa gojąco i silnie nawilżająco, a wywar bulw lilii był w przeszłości stosowany do leczenia wrzodów i zapaleń skóry. Kozie mleko od wieków było stosowane do wygładzania i nadawania skórze miękkości.

Podsumowując: woda kosmetyczna wedtug przepisu Happena to rodzaj tłustego serum koloru szarego, o świeżym zapachu, silnie natłuszczającego, działającego tonizująco, a także przeciwzapalnie (ilustracja 4). 


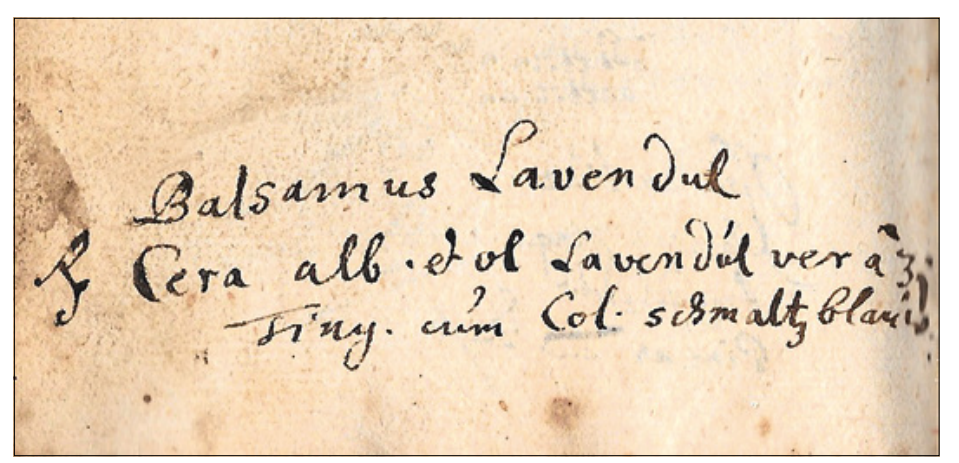

Ilustracja 5. Przepis na balsam lawendowy w manuale Happena.

Użyta w oryginale forma balsamus (rodzaj męski) jest niepoprawna (powinno być balsamum - rodzaj nijaki).

Niżej: dwie strony w manuale Happena z wykazem symboli alchemicznych.
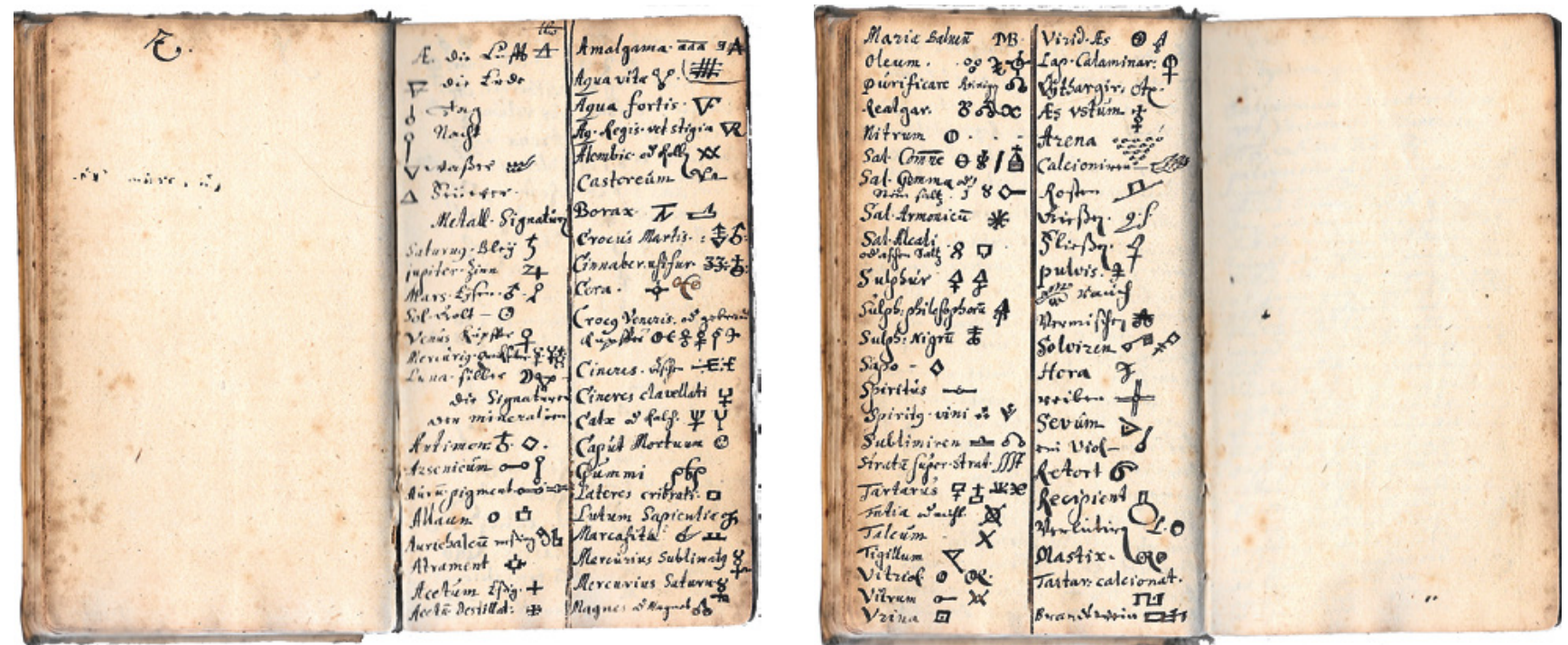

\section{Balsam lawendowy}

Wosk biaty zmieszany z prawdziwym

(tzn.niefatszowanym) olejkiem lawendowym jedna drachmę $e^{10}$.

Zlać, cedząc, do matego naczynia.

Wchodzący w skład tego balsamu wosk biały ${ }^{11} \mathrm{ma}$ działanie łagodzące, jest też bardzo dobrym emolientem. Natomiast zawarty w kwiatach lawendy olejek eteryczny, oprócz znanych właściwości zapachowych, ma też silnie działanie antyseptyczne i bakteriobójcze. Balsam lawendowy według przepisu Happena był kosmetykiem w kolorze białym, o zapachu lawendy, dość tłustym, który miał działanie natłuszczające, zmiękczające i przeciwzapalne (ilustracja 5).

\section{Proszek do zębów D. Gosk}

Pumeksu sproszkowanego 1 uncje

Korzenia fiotkowego 3 drachmy

Galbanum $^{12} z$ dodatkiem piżma 1 drachme

Olejku różanego, szatwiowego, lawendowego i cynamonu, każdego po jednym ziarnie ${ }^{13}$ Rozpuść to wszystko (w wodzie) i wysusz na podwójnej bibule Dodać piasku rzecznego biatego, ogniem najmocniejszym prażonego i doktadnie sproszkowanego cztery uncje

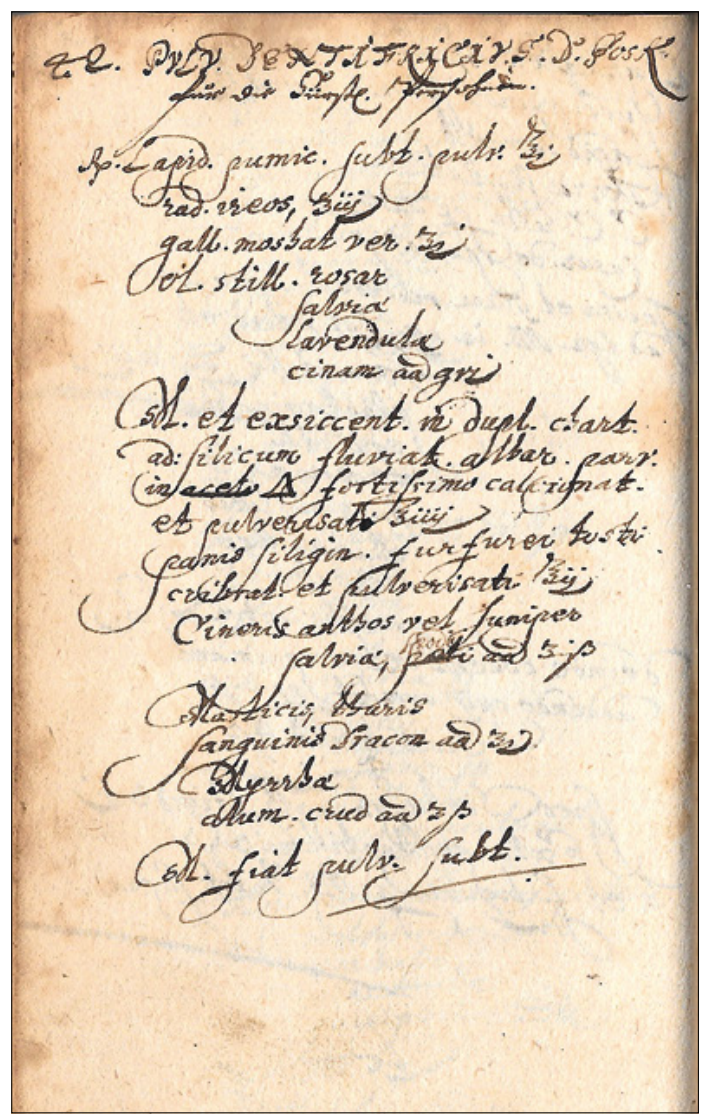

Ilustracja 6 . Przepis na ,proszek do zębów D. Gosk" w manuale Happena 
Chleba pszennego z otrębami pieczonego

i sproszkowanego i przesianego dwie uncje Spopielonego rozmarynu lub jatowca oraz szatwii, każdego póttorej drachmy Mastyksu, olibanum i smoczej krwi,

każdego jednej drachmie

Mirry $i$ atunu po pót drachmy

Zmieszaj i sproszkuj jak najmielej.

Wymienione w tytule tego przepisu określenie „D. Gosk” oznacza autora przepisu, czyli nieznanej skądinąd osoby (być może lekarza, jeśli D. oznacza Doktor) o nazwisku Gosk. To samo nazwisko powtarza się w manuale Happena jeszcze dwukrotnie (w tytułach przepisów na balsam woskowy - oryg. Balsamus Ceratalis Gosk i „wodę życia dla kobiet” - oryg. Aqua vitae mulierum Gosk). Analogiczne tytuly przepisów, z podaniem nazwiska autora lub przynajmniej nazwiska osoby, która taki czy inny przepis udostępniła, to częste zjawisko w przechowywanych w bibliotece Muzeum Farmacji aptekarskich manuałach ${ }^{14}$.

Składniki myjące (de facto ścierne) w proszku do zębów wedtug przepisu Goska-Happena to sproszkowany pumeks, wyprażony i sproszkowany piasek, ałun, spopielone (w piekarniku) rozmaryn lub igły

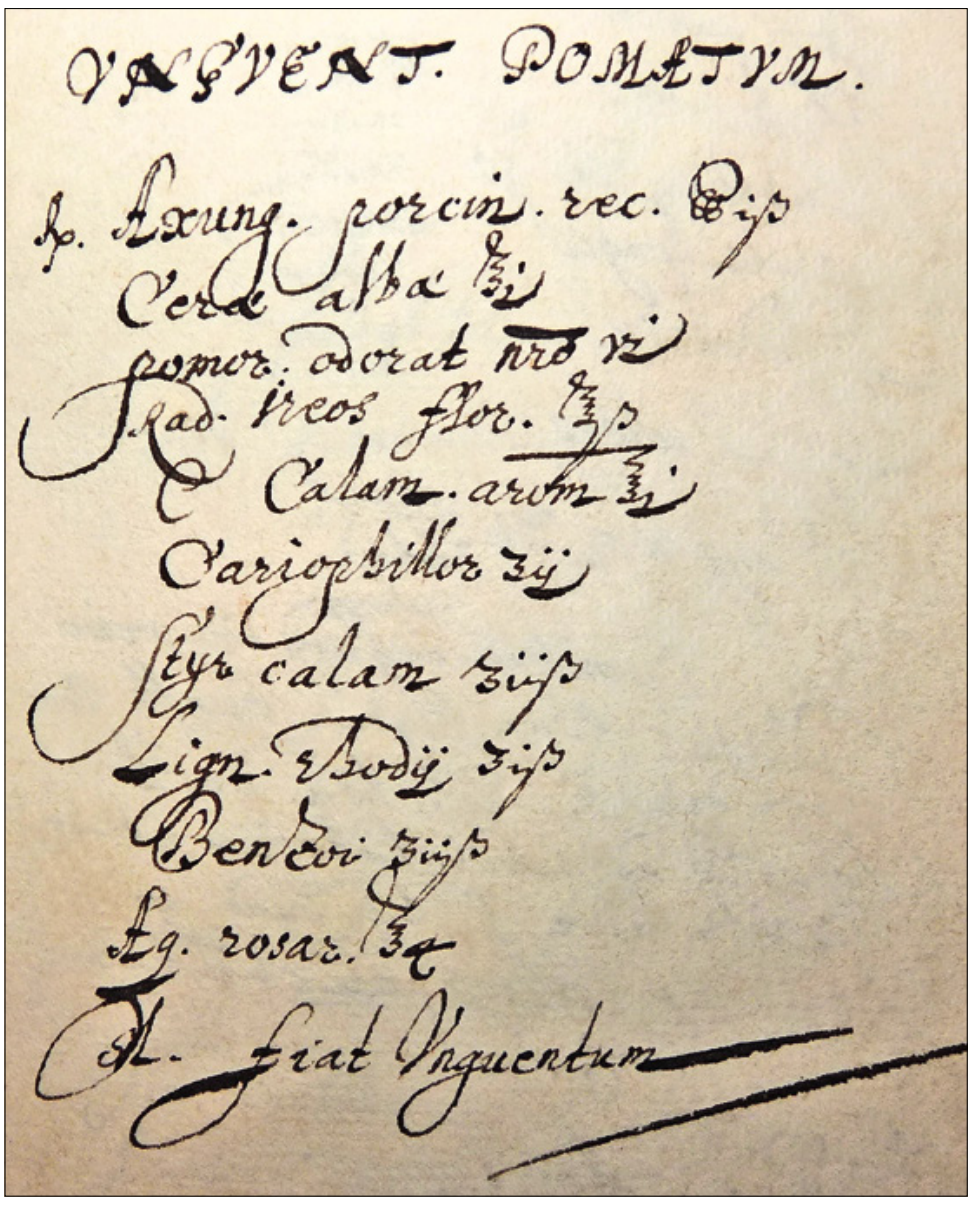

Ilustracja 7. Przepis na balsam jabłkowy w manuale Happena jałowca, liście szałwii oraz wysuszony i sproszkowany chleb. Korzeń (kłącze) kosaćca, oprócz właściwości zapachowych (po wysuszeniu nabiera przyjemnego zapachu) działa też przeciwzapalnie, podobne właściwości mają wymienione w przepisie żywice: galbanowa, mirrowa, mastyksowa, olibanum ${ }^{15} \mathrm{i}$ tzw. smocza krew ${ }^{16}$, a także olejki: różany, szałwiowy, lawendowy i cynamonowy, które odświeżają jamę ustną. Piżmo to znana powszechnie substancja zapachowa, natomiast ałun ma znane właściwości ściągające i aseptyczne (ilustracja 6). Krótko mówiąc, proszek do czyszczenia zębów według przepisu Happena składa się z substancji ściernych, takich jak pumeks czy prażony i roztarty pasek (co niekoniecznie dobrze działało na szkliwo) i licznych naturalnych substancji odkażających i odświeżających zapach jamy ustnej.

\section{Balsam jablkowy}

Świeżego ttuszczu wieprzowego 1,5 funta

Wosku biatego 1 uncje

Jabtek pachnacych 5 sztuk

Korzenia fiotkowego 0,5 uncji

Tataraku ${ }^{17} 1$ uncje

Goździków 2 drachmy

Drzewa różanego ${ }^{1 / 2}$ drachmy

Belzoinu 21/2 drachmy

Wody różanej 1 uncje

Rozpuść, zrób balsam.

Użyta przez Happena nazwa unguentum, oznaczająca we współczesnej farmacji maść (w przeszłości też olejek i krem), w tym wypadku, sądząc z charakteru składników, była kosmetykiem określanym współcześnie jako balsam do ciała. Natomiast drugi człon nazwy, pomatum, należy przetłumaczyć jako 'jabłeczny' lub 'z dodatkiem jabłek' - jako że jeden ze składników to pomae odorate, czyli 'jabłka pachnące' ${ }^{18}$. Funkcję bazy tego kosmetyku pelnit wosk biały $^{19}$, który zmiękczał i natłuszczal skórę, świeży tłuszcz wieprzowy działał silnie natłuszczająco, a także odżywczo. Gotowane jabłka pełnity funkcję nawilżającą. Kolejne składniki (korzeń kosaćca, żywice balsamiczne, woda różana itd.) pełniły rolę aromatyzującą. W sumie opisane w manuale Happena unguentum pomatum było kosmetykiem przyjemnie pachnącym, o wlaściwościach odżywczych i silnie natłuszczających (ilustracja 7).

\section{Woda na dziąsla}

Suszonych ptatków róży czerwonej, kwiatów granatu $i$ kory tamaryszkowej20 po 1 uncji Zagęszczonego soku malinowego, korzenia wrotyczu ${ }^{21} i \dot{z} y w i c y$ mastyksowej po ${ }^{1 / 2}$ uncji Atunu 2 uncje

Wody (tzn. destylatu) z owoców tarniny, polnych gruszek, świdośliwy ${ }^{22} i$ pigwy, a także czerwonego wina, każdego z tych ile trzeba. 
Rzeczy suche, grubo pokruszone, maceruj w tych wodach i winie przez 8 dni, potem dwukrotnie destyluj w kapieli wodnej, przechowuj $w$ naczyniu szklanym dobrze zamkniętym.

Podobnie jak w tytule przepisu na proszek do zębów, również tutaj wyraz „Konerd” oznacza zapewne nazwisko (lub skrót nazwiska) nieznanego skądinąd autora przepisu. Natomiast o właściwościach poszczególnych składników można powiedzieć, co następuje: kwiatów róży i granatu używano m.in. do leczenia stanów zapalnych jamy ustnej, tych drugich używa się również współcześnie, m.in. do produkcji preparatów dentystycznych. Wywar z kory tamaryszka ma silne działanie przeciwzapalne. Zagęszczony sok z malin ${ }^{23}$ jest bogaty w glikozydy, flawonoidy i witaminę C, która uszczelnia naczynia krwionośne i tamuje krwawienia, zaś zagęszczony sok owoców tarniny ma właściwości ściągające. Wywar z wrotycza stosuje się m.in. do produkcji preparatów służących do płukania jamy ustnej po zabiegach dentystycznych, a także w postaci pastylek do ssania, które są zalecane w suchości jamy ustnej i gardła, ponieważ powodują zwiększone wydzielanie śliny. Żywica mastyksowa ma właściwości bakteriobójcze i grzybobójcze, jej żucie od najgłębszej starożytności było sposobem na odkażanie jamy ustnej. Atun potasowy posiada znane właściwości ściągające i antyseptyczne, podobne właściwości mają tzw. wody (de facto destylaty) z niedojrzałych owoców tarniny polnych gruszek, owoców mespilowych (świdośliwy) i pigwy. Podsumowując: tytułowa „woda do dziąsel” to płynny preparat ciemnoczerwonego lub ciemnobrązowego koloru, o orzeźwiającym, lekko cytrusowym zapachu, który miał działanie ściągające i przeciwzapalne, a także odświeżające jamę ustną (ilustracja 8).

\section{(Galki mydlane pachnące)}

Mydta weneckiego ${ }^{24} 1$ funt

Sproszkowanego blajwasu 2 uncje

Korzenia kosaćca 1 uncje

Korzenia cibory ${ }^{25} 2$ drachmy

Oleju wajnsztynowego przez rozptynięcie się

otrzymanego $0^{26} 1$ uncje

Styraku ptynnego ${ }^{27} 1$ drachme

Kamfory pót skruputu ${ }^{28}$

Olejkuz drewna różanego ${ }^{29}$ i goździkowego

Zrób gatki o wadze jednej uncji

po 15 kropli

Nawias przy tytule tego przepisu, ze względu na jego brak w wersji oryginalnej, jest hipotetyczny - zostal utworzony przez autorów tego artykutu na podstawie zaprezentowanych w tym przepisie składników, a także polecenia, aby końcową mieszaninę uformować w gatki (oryg. globulae). O tym,

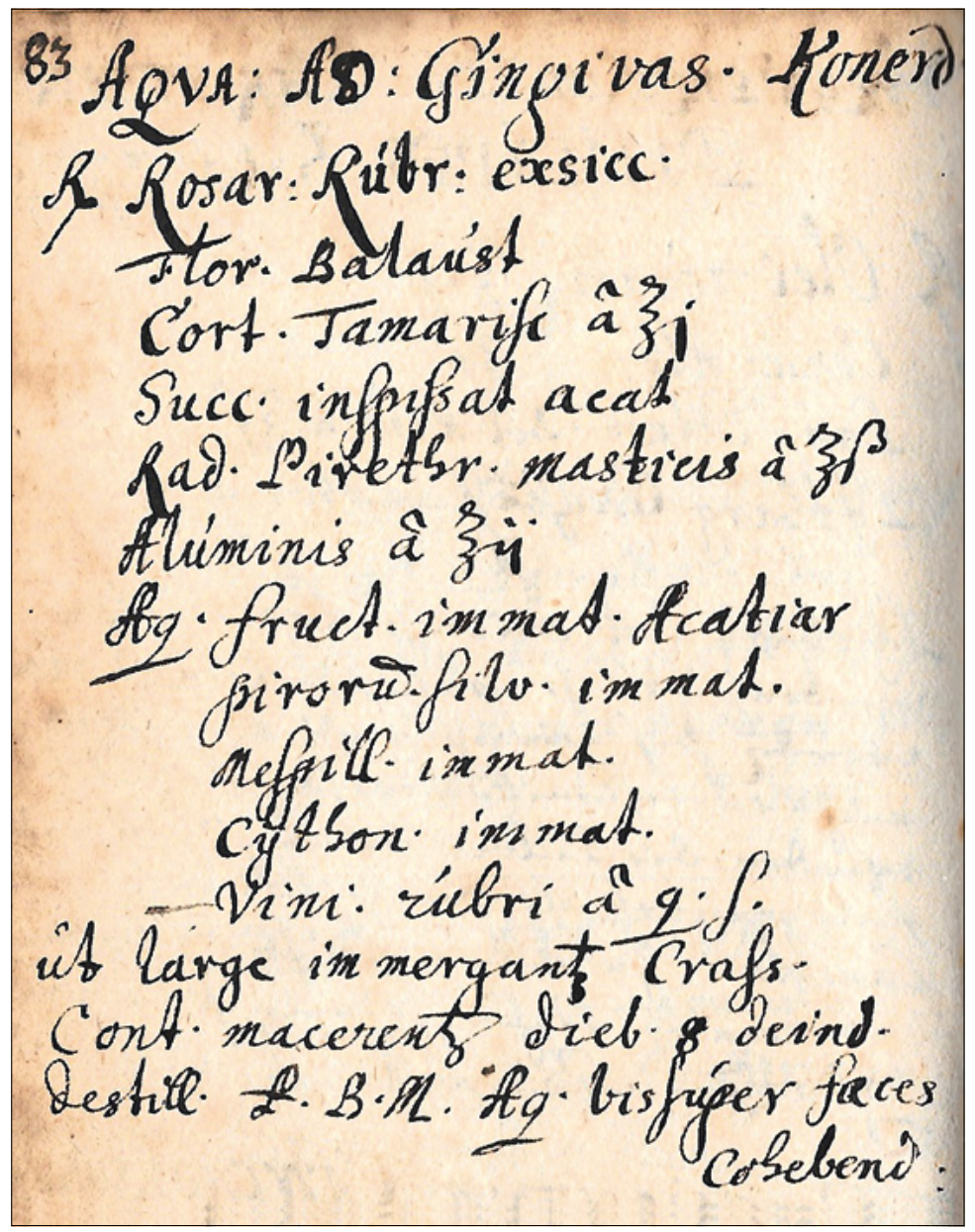

Ilustracja 8. Przepis na „wodę na dziąsła” w manuale Happena

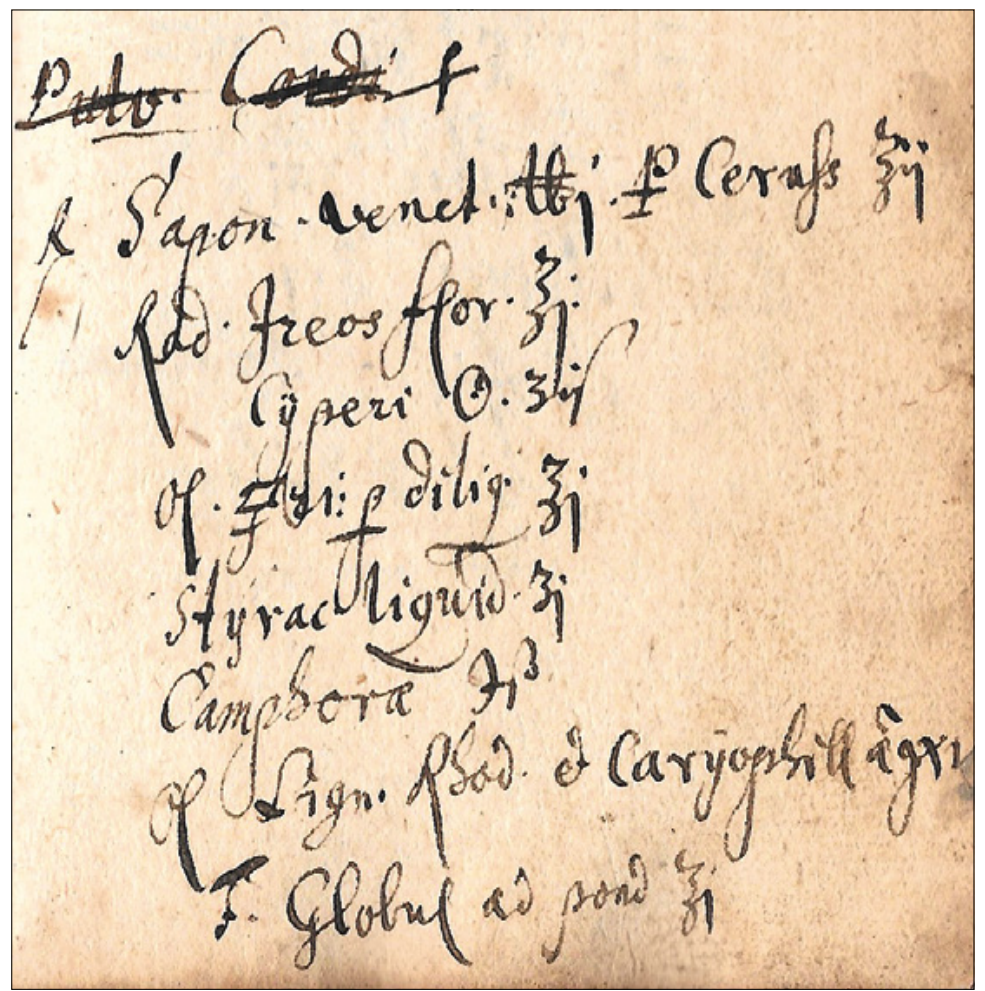

Ilustracja 9. Przepis na „gatki mydlane” w manuale Happena 
że była to stosowana w przeszłości forma mydła, świadczy informacja zawarta $\mathrm{w}$ dalszym ciągu cytowanego już tutaj przepisu na mydło białe (zob. przypis 1): „...z którego chceszli gatki albo co innego czynić”.

Drugi składnik tego mydła, blajwas, to spolszczona $\mathrm{z}$ niemieckiego bleiweiss ${ }^{30}$ nazwa bieli ołowianej (chemicznie węglan ołowiu), który w dawnym lecznictwie był stosowany głównie jako składnik maści na świerzb czy wszawicę. Korzeń kosaćca, oprócz znanych właściwości zapachowych, stosowano jako substancję oczyszczającą skórę ${ }^{31}$. Czerwony korzeń cibory (Cyperus longus L.) to znana od dawna substancja zapachowa, podobnie jak kamfora. Krótko mówiąc, opisane przez Happena mydło służyło zapewne pielęgnacji skóry problematycznej i chorobowo zmienionej (trądzik, wrzody, świerzb itp.).

Zaprezentowane wyżej przepisy na kosmetyki zamieścił Happen wyłącznie w jego części galenowej (zob. wyżej, s. 1), jako że nawet z perspektywy XVII wieku miały one charakter tradycyjny, łącznie z techniką destylacji, która w Europie była rozpowszechniona przynajmniej od początku XVI wieku, głównie za sprawą publikacji Hieronima Brunschwi$\mathrm{ga}^{32}$. Oczywiście tradycyjna, by nie powiedzieć archaiczna, jest też cała zaprezentowana w tych przepisach materia cosmetica, czyli kosmetyczne surowce i sposoby ich komponowania. Co oznacza, że entuzjastów jatrochemii, do których przecież Happena jak najbardziej zaliczyć trzeba, poszukiwanie nowych substancji kosmetycznych jeszcze w tym czasie nie interesowało. Być może dlatego, że niektóre alchemiczne próby ich preparowania niekonieczne w codziennej praktyce były bezpieczne. Oto przykład: „Są jeszcze złych ludzi wiele, co rtęć palą (tzn. prażą) z kryształowym złotołuskiem (chodzi o aurypigment, $\mathrm{As}_{2} \mathrm{~S}_{3}$ ), tylko ku bieleniu twarzy zalecając. A tak dla małego zysku czynią wielką niebezpieczność, gdy niektórym paniam od niej twarz puchnie jako bęben, lepiej by takiego piorun zabił niż takowe lekarstwa czynit." ${ }_{33}$

\section{Otrzymano: 2018.05.16 - Zaakceptowano: 2018.06.05}

\section{Przypisy:}

1. Podobne przywileje mieli w Polsce aptekarze nazywani królewskimi serwitorami. „Serwitoraty albo monopolia” zostały w „Monitorze Warszawskim” z 1774 roku określone jako „zaraza handlu” - tym bardziej, że ówczesne apteki handlowały nie tylko lekami, ale wieloma innymi towarami, z drewnem i suknem włącznie. Więcej na ten temat zob. L. Kostrzeński, Materiały do historii aptek wielkopolskich.

2. Tego rodzaju zestaw przepisów - „, chymicznych” i „galenowych” - jest charakterystyczny dla siedemnastowiecznego piśmiennictwa farmaceutycznego, będącego wyrazem powszechnego już w tym czasie przekonania, że nowe leki, uzyskiwane za sprawą alchemicznych eksperymentów, zwłaszcza tych z udziałem związków metali (antymonu, rtęci, arsenu, ołowiu itd.), są przynajmniej tak samo dobre, o ile nie lepsze, niż leki tradycyjne (określane jako galenowe, tzn. opracowane jeszcze w greckiej starożytności i arabskim średniowieczu). Na przykład van Helmont, jeden z koryfeuszy jatrochemicznego okresu historii farmacji, pisat na ten temat $\mathrm{w}$ taki oto sposób: „Weźmy ze szpitali 200 albo 500 chorych na malarię, zapalenie płuc czy inne choroby, i podzielmy ich na dwie równe połowy, według tego jak los wskaże. Wy (tzn. lekarze tradycyjni) leczcie ich swoimi lekami (tzn. tradycyjnymi, ,galenowymi”), a ja będę leczył moimi (tzn. „chymicznymi”). I zobaczymy, kto będzie miał więcej pogrzebów". Biorąc pod uwagę ówczesny stan medycyny i farmacji, pogrzebów prawdopodobnie byłoby tyle samo - ale znaczący i charakterystyczny jest tutaj fakt, jak bardzo van Helmont i jemu podobni byli przekonani o tym, $w$ jakim kierunku medycyna i farmacja powinny się rozwijać.

3. Łac. regulus - 'mały król' (zdrobnienie od lac. rex - król); w terminologii alchemicznej regulus to czysty, metaliczny antymon (rex to alchemiczna nazwa złota).

4. Jedna z grup leków złożonych $\mathrm{w}$ farmakopei florenckiej to locchi. W drugim jej wydaniu ich definicja jest następująca: „Ten rodzaj leku Arabowie nazywają Loh, Grecy Elemi, a łacinnicy Lincti, ponieważ zażywamy je przez usta w taki sposób, że je po troszeczkę zlizujemy, umożliwiając w ten sposób przenikanie do płuc.

5. William Heberden, lekarz angielski, który jako pierwszy publicznie zakwestionował medyczną przydatność tych kompozycji, za sprawą broszury pt. Antyteriak. Esej o mitrydacie i teriaku (Londyn, 1745).

6. $30,1 \mathrm{dkg}$

7. $25,1 \mathrm{~g}$

8. Dwie nogi cielęce sa też składnikiem sto lat wcześniejszego przepisu na tzw. wódkę (destylat), której celem było „lica odmłodzenie baby starej, aby się zdała we dwudziestu leciech”. W tym celu dwie nogi cielęce należało gotować „w ośminaście funtów wody rzecznej”, następnie dodać do tego ryż, miąższ chlebowy moczony w mleku, masło świeże niesolone i „,białki ze skorupami od dziesięciu jajec świeżych”. „To wszystko zmieszawszy warz, potym wypal (tzn. destyluj), aby wszystka wódka wyszła". (Alexego Pedemontana Tajemnice. W: M. Siennik, Herbarz, Kraków 1568, s. 509 A)

9. Powłoka (tzw. film) na powierzchni skóry, której zadaniem jest szybsza resorpcja składników aktywnych, a także uniemożliwienie szybkiej utraty wody z naskórka. Okluzja w kosmetyce powstaje po aplikacji kosmetyku, na przykład maseczki do twarzy.

10. $3,14 \mathrm{~g}$

11. Sposób bielenia - de facto oczyszczania wosku żóltego - na przykład w Aleksego Pedemontana Tajemnicach (op. cit.) jest następujacy: „Wosku bielenie. Weźmij wosku, ile bielić chcesz, wody stokowej (tzn. źródlanej) tyle dwoje (tzn. dwa razy więcej), wstaw wespół do ognia, niech się rozpuści, także chwilę poniechaj, aż wszystek wosk wypłynie na wierzch wody. Weźmij jakie naczynie pośklenione, coby zewnątrz było gładkie, zmaczajże je w zimnej wodzie, a wraź w on wosk do połowice, a co na nim wosku przylgnie, niech ostygnie, obtup ten wosk tak cieniuchno z naczynia, a zaś takież wrażaj i obłupuj, póki co na wodzie pływa. On potym wosk obłupiony na słońce wytóż, zwłaszcza na majową rosę, często obracając tak długo, aż wybieleje jako ołowna biel, to jest blajwas. Niektórzy go tak do trzech dni wybielą, tak się z nim sprawując, zwłaszcza w ten czas, gdy słońce jest najgorętsze, a to iż wosk cienki, będzie więc się łatwo przetapiał. Przeto dwakroć przez dzień pokrapiają go wodą studzienną."

12. Gumożywica wydzielana $z$ łodyg i kłącza bylin Ferula galbaniflua.

13. Łac. granum - $0,05 \mathrm{~g}$

14. Zwykle jest to nazwisko lub pierwsza litera nazwiska jakiego lekarza, $\mathrm{np}$. Woda do ust dr Jonas w aptekarskim manuale Kazimierza $(\mathrm{Mu}-$ zeum Farmacji UJ, sygn. 5690, s. 245) czy Eliksir do zębów dr Ciunkiewicza w manuale Antoniego Ryla (Muzeum Farmacji UJ, sygn. 7668, s. 106). Taki zwyczaj ma swoje źródło w starożytnym piśmiennictwie farmakologicznym. Na przykład tytuły przepisów zamieszczonych w traktacie Galena $\mathrm{O}$ antidotach to m.in. Antidotum Antypatra, Uniwersalne antidotum, na które przepis dostałem od Aphroda itp.

15. Oryg. thuris - skrót od manna thuris (mianownik thus, dopełniacz thuris), zwana też olibanum - żywica pozyskiwana z drzew rodzaju Boswellia, które rosną na półpustyniach i obrzeżach pustyń pótnocno-wschodniej Afryki i na Półwyspie Indyjskim. Świeżo wypływająca z drzew żywica ma postać soku, który szybko krzepnie, tworząc pachnącą, ziarenkowatą, żółtawobrązową masę.

16. Łac. Sanguis draconis - czerwona żywica pozyskiwana z palm gatunku Daemonorops draco (Azja Południowo-Wschodnia).

17. Chodzi o kłącze tej rośliny, łac. Rhizoma Calami.

18. W Aleksego Pedemontana Taiemnicach (Kraków, 1568), które są staropolskim tłumaczeniem włoskich Sekretów Aleksego z Piemontu (Wenecja, 1555) czytamy m.in. o „ttustości wonnej jabłecznej, Włoszy zową pomata” (s. 564D) i o „drugiej ttustości jabłecznej, co Włoszy pomatą zową" (s. 565F). Od łacińskiego wyrazu pomum (owoc) pochodzi francuskie pomme (jabłko). Gatunek jabłek stosowanych do takich celów określa Siennik jako „słodkie a wonne, i piękne żółte" (s. $522 \mathrm{~A})$

19. Zob. wyżej, przypis 11 
20. Tamaryszek - rodzaj krzewów lub małych drzew, rosnących na pótpustyniach i stepach południowej Europy, północnej Afryki i Azji.

21. Wrotycz (zlocień) maruna, Tanacetum parthenium L.

22. Świdośliwa Lamarca (Amelanchier lamarckii), w smaku podobna do borówki amerykańskiej, zawiera duże ilości witamin z grupy B, potas, wapń i żelazo i liczne minerały.

23. Czyli de facto tzw. rob lub roob - dawna postać leku wprowadzona do medycyny przez lekarzy arabskich, o której w Farmakopei florenckiej z 1555 roku czytamy, że jest to „sok niektórych owoców zagęszczony na słońcu albo na ogniu, tak aby można go było przechowywać i używać przede wszystkim przy niedyspozycjach ust (warg), sam lub zmieszany z miodem lub z cukrem, lub z moszczem. Ma trwałość jeden rok, a przechowuje się go w naczyniach szklanych lub glinianych glazurowanych."

24. Tzn. białe. „Mydło proste jak ubielić. Weź mydła pospolitego, nakraj go drobno, ile chcesz mieć, włóż go w kociołek i postaw na dynarku (trójnóg służący za podstawkę pod garnek lub kociol), abyś podeń mógł węgle podkładać, póki się nie rozpuści. Ale gdy się rozpuści, dodaj wody tak dużo, aby mydło wyplynęta, niech tak chwilę wre, potem ochłódź, mydło po wierzchu pływające zbieraj jaką warzechą, to będziesz miał lutrowane (oczyszczone) mydto białe." (Aleksego Pedemontana Tajemnice, op. cit. s. 565A)

25. Cyperus longus L.

26. Łac. oleum per deliquium paratum. Wajnsztyn - z niem. Wein stein kamień winny, winian potasowo-sodowy, łac. Tartarus. „Ten kamień palą w garncu do pieca wstawiwszy, iż będzie szczery wągiel, ono wę gle sttukłszy, w barchanowym worku do piwnice wieszają, z tego olej wykapie piękny. Ten olejek wiele szkaradości z lica ściera i krosty leczy.” (M. Siennik, Herbarz, op. cit. s. 264 D).

27. Żywica ambrowca wschodniego (Liquidambar orientalis Miller), określana angielskimi nazwami oriental sweet gum lub Turkish sweet gum, a także asiatic storax i levant storax.

28. 1,05 grama.

29. Drzewo różane (Convulsus floridus; dawna łacińska nazwa Lignum Rhodii) - krzew rosnący na Wyspach Kanaryjskich, którego drewno ma różany zapach. Produkowany z niego olejek był tańszym odpowiednikiem olejku różanego.

30. „Biel ołowna, którą Blaywaysem drudzy zowią” (S. Syreński, Zielnik. Kraków, 1613, s. 343).

31. J. Quincy, Pharmacopoeia Officinalis et Extemporanea. London, 1782, s. 153.

32. Liber de arte distillandi (Książki o sztuce destylacji - Strassburg, 1505), Liber de arte distillandi Simplicia et Composita (Książka o sztuce destylowania leków prostych i złożonych - Strassburg, 1505), Liber de arte distilandi Simplicia et Composita (Książka o sztuce destylowania leków prostych i złożonych - Strassburg, 1508) i Liber de arte distilandi de Compositis (Książka o sztuce destylowania leków złożonych - Strassburg, 1512).

33. Aleksego Pedemontana Tajemnice, op. cit. 